\title{
Effect of extruded cotton and canola seed on unsaturated fatty acid composition in the plasma, erythrocytes and livers of lambs
}

\author{
A. Sheikh Ahmadi ${ }^{1}$, A. Golian ${ }^{2}$, A. Akbarian ${ }^{2 \#}$, M.H. Ghaffari ${ }^{2}$, H. Shirzadi ${ }^{3}$ \\ and M. Mirzaee ${ }^{4}$ \\ ${ }^{1}$ Department of Animal Science, Faculty of Agriculture, University of Kurdistan, Sanandaj, Iran \\ ${ }^{2}$ Centre of Excellence in the Animal Science Department, Ferdowsi University of Mashhad, Mashhad, Iran \\ ${ }^{3}$ Department of Animal Science, Faculty of Agriculture, Tarbiat Modares University, Tehran, Iran \\ ${ }^{4}$ Department of Animal Science, Isfahan University of Technology, Isfahan, Iran
}

\begin{abstract}
An experiment was conducted to study the effects of extruded cotton seed (ECOS) and canola seed (ECAS) in the diet of male Mehraban lambs on the concentration of unsaturated fatty acids in their plasma, erythrocytes and livers. The treatments were: (1) control (C); (2) diet C+6\% ECAS, (3) diet C+6\% ECOS, (4) diet $\mathrm{C}+12 \%$ ECAS, (5) diet $\mathrm{C}+12 \%$ ECOS, (6) diet $\mathrm{C}+6 \%$ ECAS $+6 \% \mathrm{ECOS},(7)$ diet $\mathrm{C}+12 \% \mathrm{ECAS}$ $+6 \%$ ECOS, (8) diet C $+6 \%$ ECAS $+12 \%$ ECOS, (9) diet C $+12 \%$ ECAS $+12 \%$ ECOS, (10) diet C $+18 \%$ ECAS $+18 \%$ ECOS. A complete randomized experimental design was applied. Sixty lambs (5 - 6 months of age) were randomly allocated to the 10 dietary treatments in order to have six lambs (replicates) per diet. The lambs were housed in individual pens. The average weight of lambs at the onset of the study was $34.3 \pm 2.12$ $\mathrm{kg}$. The experiment lasted for 90 days. Results indicated that the concentration of oleic acid (C18:1), linoleic acid (C18:2 n-6) and linolenic acid (C18:3n-3) in the plasma and oleic acid and linolenic acid in erythrocyte lipids were higher in lambs fed diets containing oil seeds or a combination of the oil seeds compared to those receiving the control diet. The supplementation of $6 \%$ and $12 \%$ ECAS increased the linoleic acid concentration in the liver lipids significantly compared to those fed the diets containing ECOS. There was a linear correlation between linoleic acid content of the liver and levels of dietary ECAS and ECOS. This study provides evidence that dietary oleic acid, linoleic acid and linolenic acid might escape biohydrogenation in the rumen and showed that the type of dietary fat has a marked impact on lipid metabolism in the liver.
\end{abstract}

Keywords: Extruded oil seed, fatty acid, lamb plasma, liver, Mehraban lambs

${ }^{\#}$ Corresponding author. E-mail: aakbary60@yahoo.com

\section{Introduction}

The feeding of extra linoleic acid (C18:2 n-6) in the form of soyabean oil caused a marked increase in the concentration of this fatty acid in the plasma of goats (Yeom et al., 2003). It follows that, even though unsaturated fatty acids in the diet are extensively hydrogenated by microorganisms in the rumen (Bickerstaffe et al., 1972), the fatty acid composition of plasma lipids in ruminants can be influenced by the diet (Moore et al., 1968). Canola seed contains approximately $20 \%$ protein and $38 \%$ fat and can serve as a source of protein and energy to livestock (Kercher et al., 1990a; b). Of the $38 \%$ fat in canola seed, $65 \%$ consists of oleic acid. Cotton seed oil contains $70 \%$ unsaturated fatty acids including $18 \%$ monounsaturated (oleic), $52 \%$ polyunsaturated (linoleic) and $26 \%$ saturated (primarily palmitic and stearic) fatty acids. Diets rich in PUFA lead to higher susceptibility of plasma lipids to peroxidation compared to diets rich in SFA or monounsaturated fatty acids (Kratz et al., 2002). Moore et al. (1968) showed that the fatty acid composition of plasma lipids of ruminants can be influenced by their diet. Intraruminal infusion of $60 \mathrm{~g}$ linoleic acid $(70 \%$ purity) over a period of five days in sheep raised the concentration of linoleic acid in plasma significantly (Moore et al., 1968). The concentrations of linoleic acid in plasma and milk were reported to increase when dairy cows consumed high levels of high linoleic acid containing diets (Loor et al., 2002; Petit, 2002). However, the oleic acid concentration of liver fat and adipose tissue remained unchanged in adult goats that consumed a large quantity of calcium oleate (Van den Top et al., 1995). In another study Yeom et al. (2003) noted that the fatty acid composition of erythrocytes in goats, unlike plasma lipids, was not influenced when a ration rich in soyabean oil was fed for a period of 21 days. This might be related to the short experimental 
period of 21 days, considering the 125-day lifespan of erythrocytes in goats (Ruckebusch et al., 1991). The fatty acid composition of erythrocytes can be affected by high intakes of polyunsaturated fatty acids, as shown in rats (Periago et al., 1990), calves (Sklan et al., 1972) and goat kids (Yeom et al., 2002). Feeding extra linoleic acid (C18:2 n-6) in the form of soyabean oil caused a marked increase in the concentration of this fatty acid in the plasma of goats (Yeom et al., 2003). Furthermore, it suggests that products from animals fed linseed (Bauman et al., 2005) and canola seed (Ghaffari et al., 2010) that contain high levels of C18:2 cis-9, trans-11, which is an isomer of conjugated linoleic acid (CLA), might have a positive effect on human health by decreasing the incidence of cancer.

Oilseeds can be fed either as whole seeds or processed. Different techniques of processing can be used, with extrusion being the most common one. Since the extrusion process breaks down plant cells, it can be expected that the cytosolic triglycerides would be more accessible to rumen bacteria than when whole seed is fed, because they are more readily available for lipolysis and biohydrogenation (Maddock et al., 2006). Gonthier et al. (2004) found that although extrusion increased the disappearance of linolenic acid, it also increased the proportion of intermediate compounds such as trans 18:1 fatty acids in the duodenal flow. The main goal of this study was to examine the effect of increasing levels of extruded cotton seed and canola seed on oleic acid, linoleic acid and linolenic acid concentrations of the plasma, erythrocytes and livers of male Mehraban lambs.

\section{Materials and Methods}

This experiment was carried out at the Animal Research Station, Agricultural Technical Schools Fasa, Shiraz, Iran. All experimental procedures used in this experiment were approved by the Animal Care Committee of the Agricultural Technical Schools, Fasa.

Sixty male Mehraban lambs, $5-6$ months of age with an initial weight of $34.3 \pm 2.1 \mathrm{~kg}$, were placed individually in 60 pens $(1 \times 1.5 \mathrm{~m})$ and randomly assigned to one of 10 dietary treatments, constituting six lambs (replicates) per treatment. The animals were kept under natural daylight and their health was monitored throughout the experiment. The 10 dietary treatments were as follows: the Control diet without extruded oil seed; diets containing 6\% extruded canola seed (6\% ECAS); $6 \%$ extruded cotton seed $(6 \%$ ECOS); $12 \%$ ECAS; $12 \%$ ECOS; $6 \%$ ECAS $+6 \%$ ECOS; $12 \%$ ECAS $+6 \%$ ECOS; $6 \%$ ECAS $+12 \%$ ECOS; $12 \%$ ECAS $+12 \%$ ECOS and 18\% ECAS + 18\% ECOS. During a 12-day adaptation period, incremental portions $(25,50,75$, and $100 \%)$ of a concentrate containing equal amounts of extruded canola seed and extruded cotton seed substituted the basal concentrate, and were fed with forage as a total mixed diet. The ECOS and/or ECAS were mixed with the concentrate before the lambs were fed. The lambs were fed twice daily at 8.00 and 17.00 in equal portions with a total of $1.4 \mathrm{~kg}$ feed per/lamb/day. Each diet was offered as a total mixed ration (TMR) consisting of $20 \%$ maize silage, $20 \%$ lucerne hay and $60 \%$ concentrate. Feed refusals were registered daily. The ingredients and chemical composition of the concentrates in the treatments are presented in Table 1 . The fatty acid composition of the cotton seed and canola seed is presented in Table 2. The crude protein and fat content the experimental diets were determined using the methods described by the AOAC (1990) and neutral detergent fibre (NDF) content was determined by the methods of Van Soest et al. (1991). The content of the metabolizable energy (ME, MJ/kg DM) was calculated as described by Alderman (1985).

The experimental lambs were slaughtered at a commercial abattoir after 90 days at an average final live weight of $51.6 \pm 2.33 \mathrm{~kg}$. On the last day of the experiment prior to the morning meal blood samples were taken from the jugular vein into EDTA-containing vacutainers. The blood samples were immediately centrifuged at $2700 \mathrm{rpm}$ for $5 \mathrm{~min}$. to separate plasma from the cells. The plasma was collected and stored at $-20{ }^{\circ} \mathrm{C}$. The erythrocytes were washed twice with cold, isotonic saline. The buffy coat was removed and the washed erythrocytes were frozen at $-20^{\circ} \mathrm{C}$. Immediately after slaughter the whole liver was removed from the carcass, snap-frozen in liquid nitrogen and stored at $-20^{\circ} \mathrm{C}$. Total lipids were extracted from plasma, erythrocyte and liver samples to determine their fatty acid composition by gas chromatography with a CPFFAP CB column ( $25 \mathrm{~m} \times 0.32 \mathrm{~mm}$ i.d., Varian BV/Chrompack, Middelburg, The Netherlands) equipped with a flame ionization detector. The carrier gas was hydrogen and the oven temperature was programmed at $120{ }^{\circ} \mathrm{C}$ and held for $1 \mathrm{~min}$, then increased to $180{ }^{\circ} \mathrm{C}$ at a rate of $5^{\circ} \mathrm{C} / \mathrm{min}$, held for $18 \mathrm{~min}$, increased to $200{ }^{\circ} \mathrm{C}$ at $2{ }^{\circ} \mathrm{C} / \mathrm{min}$, held for $1 \mathrm{~min}$, increased to $230{ }^{\circ} \mathrm{C}$ at a rate of $2{ }^{\circ} \mathrm{C} / \mathrm{min}$ and held for $19 \mathrm{~min}$. The 
Table 1 Dietary ingredients and nutrient composition of the experimental diets

\begin{tabular}{|c|c|c|c|c|c|c|c|c|c|c|}
\hline \multirow[b]{2}{*}{ Diet } & \multicolumn{10}{|c|}{ Concentrates $^{1}$} \\
\hline & Control & $\begin{array}{c}6 \% \\
\text { ECAS } \\
\end{array}$ & $\begin{array}{c}6 \% \\
\text { ECOS } \\
\end{array}$ & $\begin{array}{c}12 \% \\
\text { ECAS } \\
\end{array}$ & $\begin{array}{c}12 \% \\
\text { ECOS } \\
\end{array}$ & $\begin{array}{c}6 \% \text { ECAS } \\
+6 \% \text { ECOS } \\
\end{array}$ & $\begin{array}{r}12 \% \mathrm{ECAS} \\
+6 \% \text { ECOS } \\
\end{array}$ & $\begin{array}{c}6 \% \text { ECAS } \\
+12 \% \text { ECOS } \\
\end{array}$ & $\begin{array}{c}12 \% \text { ECAS } \\
+12 \% \text { ECOS } \\
\end{array}$ & $\begin{array}{c}18 \% \text { ECAS } \\
+18 \% \text { ECOS } \\
\end{array}$ \\
\hline \multicolumn{11}{|l|}{ Ingredients $(\%$ in diet $)$} \\
\hline Maize silage & 20 & 20 & 20 & 20 & 20 & 20 & 20 & 20 & 20 & 20 \\
\hline Lucerne hay & 20 & 20 & 20 & 20 & 20 & 20 & 20 & 20 & 20 & 20 \\
\hline Cotton Seed & - & - & 6 & - & 12 & 6 & 6 & 12 & 12 & 18 \\
\hline Canola Seed & - & 6 & - & 12 & - & 6 & 12 & 6 & 12 & 18 \\
\hline Barley & 53.2 & 49.2 & 52.2 & 46.3 & 46.3 & 46.3 & 40.3 & 40.3 & 34.3 & 17.2 \\
\hline Wheat bran & 5 & 3 & - & - & - & - & - & - & - & 5 \\
\hline Limestone & 0.55 & 0.55 & 0.55 & 0.45 & 0.45 & 0.45 & 0.45 & 0.45 & 0.45 & 0.55 \\
\hline Vit./min* & 0.5 & 0.5 & 0.5 & 0.5 & 0.5 & 0.5 & 0.5 & 0.5 & 0.5 & 0.5 \\
\hline Urea & 0.25 & 0.25 & 0.25 & 0.25 & 0.25 & 0.25 & 0.25 & 0.25 & 0.25 & 0.25 \\
\hline Salt & 0.5 & 0.5 & 0.5 & 0.5 & 0.5 & 0.5 & 0.5 & 0.5 & 0.5 & 0.5 \\
\hline \multicolumn{11}{|l|}{ Nutrient composition } \\
\hline Dry matter, $\mathrm{g} / \mathrm{kg}$ & 592 & 592 & 593 & 593 & 593 & 593 & 593 & 594 & 594 & 594 \\
\hline $\mathrm{CP}, \mathrm{g} / \mathrm{kg} \mathrm{DM}$ & 135 & 152 & 151 & 168 & 168 & 169 & 185 & 186 & 203 & 240 \\
\hline Crude fat, $\mathrm{g} / \mathrm{kg} \mathrm{DM}$ & 27 & 46 & 38 & 65 & 49 & 56 & 76 & 68 & 86 & 118 \\
\hline NDF, g/kg DM & 324 & 316 & 323 & 305 & 337 & 321 & 319 & 335 & 332 & 332 \\
\hline $\mathrm{ME}, \mathrm{MJ} / \mathrm{kg} \mathrm{DM}$ & 9.2 & 9.2 & 9.2 & 9.2 & 9.2 & 9.2 & 9.2 & 9.2 & 8.8 & 8.3 \\
\hline \multicolumn{11}{|c|}{ Fatty acid composition (g/kg DM) } \\
\hline C18:1 & 0.43 & 1.76 & 0.59 & 3.09 & 0.76 & 1.92 & 3.26 & 2.09 & 3.43 & 4.95 \\
\hline C18:2n-6 & 0.92 & 1.31 & 1.57 & 1.58 & 2.20 & 1.89 & 2.21 & 2.52 & 2.84 & 3.87 \\
\hline C18:3n-3 & 0.25 & 0.39 & 0.24 & 0.52 & 0.23 & 0.38 & 0.52 & 0.37 & 0.51 & 0.65 \\
\hline
\end{tabular}

${ }^{*}$ Each $\mathrm{kg}$ of vitamin/mineral premix contained: $500000 \mathrm{IU}$ vitamin A; $100000 \mathrm{IU}$ vitamin $\mathrm{D}_{3} ; 100 \mathrm{mg}$ vitamin E; $190 \mathrm{~g} \mathrm{Ca} ; 90 \mathrm{~g} \mathrm{Mg} ; 50 \mathrm{~g} \mathrm{Na} ; 2 \mathrm{~g} \mathrm{Mn} ; 3 \mathrm{~g} \mathrm{Fe} ; 0.3 \mathrm{~g} \mathrm{Cu} ; 3$ $\mathrm{g} \mathrm{Zn} ; 0.1 \mathrm{~g} \mathrm{Co} ; 1 \mathrm{mg} \mathrm{Se}$.

${ }^{1}$ Each lamb was fed $1.4 \mathrm{~kg} /$ day of a total mixed ration (TMR), consisting of $20 \%$ maize silage, $20 \%$ lucerne hay, $60 \%$ concentrate for 90 days.

$\mathrm{CP}$ - Crude protein; DM - Dry matter; NDF - Neutral detergent fibre.

ME - Metabolizable energy was calculated using the formula for compound feeds proposed by Alderman (1985).

ECOS - extruded cotton seed; ECAS - extruded canola seed. 
Table 2 Fatty acid profiles of cotton seed and canola seed

\begin{tabular}{llcc}
\hline \multicolumn{2}{c}{ Fatty acid $^{1}$} & Cotton seed & Canola seed \\
\hline Oleic acid (\%) & C18:1 & 19.29 & 47.26 \\
Linoleic acid (\%) & C18:2n-6 & 51.56 & 24.31 \\
Linolenic acid (\%) & C18:3n-3 & 0.53 & 9.52
\end{tabular}

${ }^{1} \overline{\text { Fatty acids (values are expressed as } \mathrm{g} \text { fatty acid methyl ester/100 } \mathrm{g} \text { fatty acid methyl esters). }}$.

injector temperature was set at $270{ }^{\circ} \mathrm{C}$, and the detector temperature at $300{ }^{\circ} \mathrm{C}$ (Yeom et al., 2003). Methylation of erythrocyte fatty acids was performed according to the method of Angelico et al. (1983) and the fatty acids were determined using gas chromatography.

The data were analyzed using the general linear model (GLM) procedure of SAS for windows (SAS, 2004). The effects of treatment (extruded oil seeds) were included in the model. Initial weight was used as the covariate for analysis of data. Means were compared using least square means adjusted for Duncan $(\mathrm{P} \leq 0.05)$. The single degree of freedom orthogonal contrasts was used to compare the effects of ECOS vs. ECAS, as well as ECOS vs. ECOS + ECAS and ECAS vs. ECOS + ECAS.

\section{Results and Discussion}

The effects of the diets that contained ECOS and/or ECAS on the unsaturated fatty acid composition of the plasma, erythrocytes and livers of the lambs are shown in Table 3. Concentrations of oleic acid, linoleic acid and linolenic acid in plasma lipids were significantly $(\mathrm{P}<0.05)$ affected by dietary treatments (Table 3). Feeding diets containing ECOS or ECAS increased the concentrations of oleic acid, linoleic acid and linolenic acid in plasma and oleic acid and linolenic acid in erythrocyte lipids compared to the control treatment. Yeom et al. (2005) reported that the feeding of a concentrate containing olive oil significantly elevated the oleic acid level of plasma and total lipids in goats. Feeding high levels of dietary fat tend to have an inhibitory effect on ruminal biohydrogenation and negative effect on rumen microbial fermentation (Jenkins, 1993). Marchello et al. (1972) showed that steers fed a 6\% safflower oil supplemented diet had higher serum linoleic acid (C18:2) concentrations than those fed animal fat. The highest concentrations of oleic acid, linoleic acid and linolenic acid in plasma lipids were found in the lambs fed the diet containing $18 \%$ ECAS $+18 \%$ ECOS, while the lowest concentrations were found in the control group (Table 3). This result might be related to unsaturated fatty acids that escaped biohydrogenation in the rumen and are preferentially esterified into the plasma cholesteryl esters and phospholipids. Alternatively, there might be selective incorporation of fatty acids into the membranes of erythrocytes (Sato, 1974).

Hajri et al. (2002) concluded that the cellular uptake of long chain fatty acids involves two components, a passive diffusion through the lipid bilayer and a protein-facilitated transfer. Thus, the change in fatty acid composition of plasma lipids is not fully reflected by the fatty acid composition of the erythrocytes. The reason is that the membrane fluidity of erythrocytes must be maintained (Smith, 1987; Williams \& Maunder, 1992).

The highest concentrations of oleic acid, linoleic acid and linolenic acid in erythrocyte lipids were found in the lambs fed the diets containing 18\% ECAS $+18 \%$ ECOS, while the lowest concentrations of oleic acid and linoleic acid were observed in the Control lambs (Table 3). No significant differences were observed in the concentrations of linolenic acid in erythrocyte lipids of lambs fed diets containing $6 \%$ ECAS, $6 \% \mathrm{ECOS}, 12 \% \mathrm{ECAS}, 12 \% \mathrm{ECOS}, 12 \% \mathrm{ECAS}+6 \% \mathrm{ECOS}$ or zero oil seed and those fed diets containing $6 \%$ ECAS $+6 \%$ ECOS, $6 \%$ ECAS $+12 \%$ ECOS, $12 \%$ ECAS $+12 \%$ ECOS, $18 \%$ ECAS $+18 \%$ ECOS. There were not significant differences in the concentration of linoleic acid in the erythrocyte lipids of lambs fed diets containing 12\%ECAS, $12 \% \mathrm{ECOS}, 6 \% \mathrm{ECAS}+6 \%$ ECOS, $12 \% \mathrm{ECAS}+6 \% \mathrm{ECOS}$ and those fed diets containing $6 \% \mathrm{ECAS}+12 \% \mathrm{ECOS}, 12 \% \mathrm{ECAS}+12 \% \mathrm{ECOS}, 18 \% \mathrm{ECAS}+18 \% \mathrm{ECOS}$. There are a few reports on the fatty acid composition of ruminant liver lipids (Enser et al., 1998; Rukkwamsuk et al., 2000). Our study showed that the concentration of linoleic acid in the liver of the lambs was significantly $(\mathrm{P}<0.05)$ 
Table 3 The unsaturated fatty acid composition in plasma, liver and erythrocytes of Mehraban male lambs fed diets with different levels of extruded cotton seed (ECOS) and extruded canola seed (ECAS)

\begin{tabular}{|c|c|c|c|c|c|c|c|c|c|c|c|}
\hline \multirow[b]{2}{*}{ Fatty acids } & \multicolumn{10}{|c|}{ Concentrates $^{1}$} & \multirow[b]{2}{*}{ s.e.m. } \\
\hline & Control & $\begin{array}{c}6 \% \\
\text { ECAS } \\
\end{array}$ & $\begin{array}{c}6 \% \\
\text { ECOS } \\
\end{array}$ & $\begin{array}{c}12 \% \\
\text { ECAS }\end{array}$ & $\begin{array}{c}12 \% \\
\text { ECOS }\end{array}$ & $\begin{array}{c}6 \% \text { ECAS } \\
+6 \% \text { ECOS }\end{array}$ & $\begin{array}{r}12 \% \mathrm{ECAS} \\
+6 \% \text { ECOS } \\
\end{array}$ & $\begin{array}{c}6 \% \text { ECAS } \\
+12 \% \text { ECOS } \\
\end{array}$ & $\begin{array}{c}12 \% \text { ECAS } \\
+12 \% \text { ECOS } \\
\end{array}$ & $\begin{array}{c}18 \% \mathrm{ECAS} \\
+18 \% \mathrm{ECOS} \\
\end{array}$ & \\
\hline \multicolumn{12}{|l|}{ Plasma (mg/L) } \\
\hline Oleic acid & $687.07^{\mathrm{f}}$ & $696.82^{\mathrm{def}}$ & $691.78^{\mathrm{ef}}$ & $716.07^{\mathrm{bcd}}$ & $693.14^{\mathrm{ef}}$ & $711.4^{\mathrm{dce}}$ & $724.38^{\mathrm{abc}}$ & $712.2^{\mathrm{dce}}$ & $736.9^{\mathrm{ab}}$ & $744.12^{\mathrm{a}}$ & 6.83 \\
\hline Linoleic acid & $286.00^{\mathrm{d}}$ & $297.30^{\mathrm{cd}}$ & $303.40^{\mathrm{bcd}}$ & $299.00^{\mathrm{bcd}}$ & $304.69^{\mathrm{abc}}$ & $301.3^{\mathrm{bcd}}$ & $309.61^{\mathrm{abc}}$ & $312.1^{\mathrm{abc}}$ & $316.5^{\mathrm{ab}}$ & $321.32^{\mathrm{a}}$ & 5.25 \\
\hline Linolenic acid & $39.31^{c}$ & $39.80^{\mathrm{bc}}$ & $39.70^{c}$ & $41.59^{\mathrm{abc}}$ & $42.40^{\mathrm{abc}}$ & $42.50^{\mathrm{abc}}$ & $42.40^{\mathrm{abc}}$ & $42.93^{\mathrm{ab}}$ & $43.30^{\mathrm{a}}$ & $44.78^{\mathrm{a}}$ & 1.65 \\
\hline \multicolumn{12}{|c|}{ Erythrocytes (g fatty acid methyl ester/100 g fatty acid methyl ester) } \\
\hline Oleic acid & $36.80^{\mathrm{c}}$ & $38.50^{\mathrm{bc}}$ & $38.32^{\mathrm{bc}}$ & $39.73^{\mathrm{ab}}$ & $38.94^{\mathrm{abc}}$ & $39.11^{\mathrm{abc}}$ & $40.12^{\mathrm{ab}}$ & $39.80^{\mathrm{ab}}$ & $40.24^{\mathrm{ab}}$ & $41.11^{\mathrm{a}}$ & 0.73 \\
\hline Linoleic acid & 8.03 & 8.13 & 7.47 & 7.99 & 8.19 & 8.14 & 7.55 & 7.81 & 7.90 & 8.08 & 0.21 \\
\hline Linolenic acid & $0.83^{\mathrm{c}}$ & $0.83^{\mathrm{c}}$ & $0.93^{\mathrm{bc}}$ & $0.88^{\mathrm{bc}}$ & $0.94^{\mathrm{bc}}$ & $1.03^{\mathrm{ab}}$ & $0.94^{\mathrm{bc}}$ & $1.03^{\mathrm{ab}}$ & $1.07^{\mathrm{ab}}$ & $1.15^{\mathrm{a}}$ & 0.06 \\
\hline \multicolumn{12}{|l|}{ Liver (g/kg fatty acids) } \\
\hline Linoleic acid & $26.87^{\mathrm{e}}$ & $27.45^{\mathrm{f}}$ & $27.04^{\mathrm{e}}$ & $28.51^{\mathrm{c}}$ & $28.31^{\mathrm{cd}}$ & $28.41^{\mathrm{c}}$ & $28.74^{\mathrm{bc}}$ & $28.03^{\mathrm{cd}}$ & $29.5^{\mathrm{ab}}$ & $29.95^{\mathrm{a}}$ & 0.74 \\
\hline
\end{tabular}

a, b, c, d, e, f, g Means in a row with no common superscript are significantly different $(\mathrm{P}<0.05)$.

${ }^{1}$ Each lamb was fed $1.4 \mathrm{~kg} /$ day of total mixed ration (TMR), made of $20 \%$ maize silage $+20 \%$ lucerne hay $+60 \%$ concentrate for 90 days. 
Table 4 The orthogonal contrast for the effect of extruded canola seed (ECAS) and extruded cotton seed (ECOS) or the mixture of two on plasma, erythrocytes and liver fatty acids

\begin{tabular}{lccccccc}
\hline & \multicolumn{3}{c}{ Contrasts } & \multicolumn{2}{c}{ Linear } & \multicolumn{2}{c}{ Quadratic } \\
\cline { 2 - 8 } Fatty acids & $\begin{array}{c}\text { ECOS vs. } \\
\text { ECAS }\end{array}$ & $\begin{array}{c}\text { ECOS vs. } \\
\text { ECOS }+ \\
\text { ECAS }\end{array}$ & $\begin{array}{c}\text { ECAS vs. } \\
\text { ECOS }+ \\
\text { ECAS }\end{array}$ & $\begin{array}{c}\text { ECOS } \\
\text { group }\end{array}$ & $\begin{array}{c}\text { ECAS } \\
\text { group }\end{array}$ & $\begin{array}{c}\text { ECOS } \\
\text { group }\end{array}$ & $\begin{array}{c}\text { ECAS } \\
\text { group }\end{array}$ \\
\hline Plasma & & Probability & & & & & \\
$\quad$ Oleic acid & 0.0920 & 0.0136 & 0.0136 & NS & $* * *$ & NS & NS \\
$\quad$ Linoleic acid & 0.0908 & 0.0157 & 0.0157 & $* *$ & NS & NS & NS \\
$\quad$ Linolenic acid & 0.2118 & 0.0121 & 0.0121 & NS & NS & NS & NS \\
Erythrocytes & & & & & & & NS \\
$\quad$ Oleic acid & 0.1014 & 0.0169 & 0.0169 & NS & $* *$ & NS & NS \\
$\quad$ Linoleic acid & 0.1433 & 0.3184 & 0.3184 & NS & NS & NS & NS \\
$\quad$ Linolenic acid & 0.2196 & 0.0299 & 0.0299 & NS & NS & & NS \\
Liver & & & & & & NS & NS \\
$\quad$ Linoleic acid & 0.0484 & 0.0002 & 0.0002 & $* * *$ & $* *$ & & \\
\hline
\end{tabular}

P-values of single degree of freedom orthogonal contrasts; $* * \mathrm{P}<0.01$; $* * * \mathrm{P}<0.001$; NS - not significant.

ECOS - extruded Cotton seed; ECAS - extruded canola seed.

influenced by diets containing different amounts of ECOS or ECAS, or a combination of the two. The highest concentration of linoleic acid in the liver was found in lambs fed the $18 \%$ ECAS $+18 \%$ ECOS diet, while the lowest concentration of linoleic acid was observed in those fed the Control diet (Table 3). Some fatty acids in plasma or erythrocytes responded more readily to dietary oil seeds than others. Saturated and monounsaturated fatty acids are synthesized in vivo and, as a result, are less readily influenced by diet than polyunsaturated fatty acids such as linoleic acid (18:2, n-6) and $\alpha$-linolenic acid (18:3, n-3), which to some extent reflect the dietary profile of oil (Enser et al., 2000).

Diets contained ECAS increased $(\mathrm{P}<0.05)$ the level of linoleic acid in liver lipids compared to the ECOS containing diets (Table 4). Moore \& Christie (1984) suggested that when ruminants are fed large quantities of unsaturated fats (as in the present study) the hydrogenation capacity of the rumen is exceeded. The changes in fatty acid composition of some tissues were described in lambs fed PUFA-supplemented diets (Vernon, 1975; Muci et al., 1992a; Enser et al., 1998). Chang et al. (1992) concluded that the unsaturated fatty acid composition of the ruminant tissues may be modified through the diet if the fatty acids escaped ruminal changes. The high level of linoleic acid (C18:2), as observed in this study in the livers of ECOS and/or ECAS fed lambs (Table 3) may reflect the levels of dietary C18:2 concentration of the diets tested.

The highest responses of oleic acid, linoleic acid and linolenic acid in plasma, erythrocytes and liver lipids were observed in lambs fed diets containing ECOS or ECAS compared to those containing ECOS+ECAS (Table 4). The linoleic acid concentration of liver lipids was significantly higher $(\mathrm{P}<0.01)$ in the lambs fed diets containing ECAS than lambs fed diets containing ECOS (Table 4). There was a linear correlation between different levels of ECOS or ECAS with the concentrations of oleic acid, linoleic acid in plasma and erythrocytes (Table 4). There was also a linear correlation between different levels of ECAS or ECOS with the concentrations of linoleic acid and linolenic in the liver.

\section{Conclusion}

The results of the present experiment showed that supplementing of Mehraban lambs with different levels of dietary ECAS and ECOS significantly increased the oleic acid, linoleic acid and linolenic acid concentrations in plasma. The fatty acid composition of both plasma lipids and erythrocytes may be influenced by the type of dietary oil in Mehraban lambs. Feeding diets with different levels of ECAS or 
ECOS resulted in elevated concentrations of oleic acid, linoleic acid and linolenic acid in both plasma lipids and erythrocytes, that is important for the health of animals and for their tissue deposit. The concentration of linoleic acid in the liver is likely to increase with dietary increments of ECOS or ECAS.

\section{References}

Alderman, G., 1985. Prediction of the energy value of compound feeds. In: Recent Advances in Animal Nutrition. Eds Haresign, W. \& Cole, D.J.A., Butterworths, London, UK. pp. 3-52.

Angelico, F., Arca, M., Calvier, A., Cantafora, A., Guccione, P., Monini, P., Montali, A. \& Ricci, G., 1983. Plasma and erythrocyte fatty acids: a methodology for evaluation of hypocholesterolemic dietary interventions. Prev. Med. 12, 124-127.

AOAC, 1990. Official Methods of the Association of Official Analytical Chemists. 12th ed. AOAC, Washington, D.C., USA. pp. 267-273.

Bauman, D.E., Lock, A.L., Corl, B.A., Salter, A.M. \& Parodi, P.M., 2006. Milk fatty acids and human health: potential role of conjugated linoleic acid and trans fatty acids. In: Ruminant Physiology. Eds Sejrsen, K., Hvelplund, T. \& Nielsen, M.O., Wageningen. Academic. Publishers. pp. 529-561.

Beynen, A.C., 1986. Plasma and liver cholesterol concentration in mice fed semipurified diets differing in the amount of cholesterol and dietary fat. Int. J. Vit. Nutr. Res. 56, 387-390.

Bickerstaffe, R., Noakes, D.E. \& Annison, E.F., 1972. Quantitative aspects of fatty acid biohydrogenation, absorption and transfer into milk fat in the lactating goat, with special reference to the cis- and transisomers of octadecenoate and linoleate. Biochem. J. 130, 607-617.

Chang, J.H.P., Lunt, D.K. \& Smith, S.B., 1992. Fatty acid composition and fatty acid elongase and stearoyl CoA desaturase activities in tissues of steers fed high oleate sunflower seed. J. Nutr. 122, 2074-2080.

Enser, M., Hallett, K.G., Hewett, B., Fursey, G.A.J. \& Harrington, G., 1998. The polyunsaturated fatty acid composition of beef and lamb liver. Meat Sci. 49, 321-327.

Enser, M., Richardson, R.I., Wood, J.D., Gill, B.P. \& Sheard, P.R., 2000. Feeding linseed to increase the n-3 PUFA of pork: fatty acid composition of muscle, adipose tissue, liver and sausages. Meat Sci. 55, 201-212.

Ghaffari, M.H., Tahmasbi, A.M. \& Khorvash, M., 2010. Effect of extruded cotton seed and canola seed on carcass traits and CLA content of longissimus dorsi muscle in Mehraban lambs. Res. J. Biol. Sci. 5, 199-203.

Gonthier, C., Mustafa, A.F., Berthiaume, R. Petit, H.V. \& Ouellet, D.R., 2004. Feeding micronized and extruded flaxseed to dairy cows: effects on digestion and ruminal biohydrogenation of long chain fatty acids. Can. J. Anim. Sci. 84, 705-711.

Hajri, T. \& Abumrad, N.A., 2002. Fatty acid transport across membranes: relevance to nutrition and metabolic pathology. Ann. Rev. Nutr. 22, 383-415.

Jenkins, T.C., 1993. Lipid metabolism in the rumen. J. Dairy Sci. 76, 3851-3863.

Kercher, C.J., Rule, D.C. \& Jones, R.R., 1990a. Canola vs. soybean protein sources for growing finishing beef bulls. Proc. West Sect. Am. Soc. Anim. Sci. 41, 445.

Kercher, C.J., Rule, D.C. \& Jones, R.R., 1990b. Comparison of soybean protein products with canola protein products for growing finishing steers. Ann. Coll. Agric. Prog. Rep. Agric. Exp. Sta., Univ. Wyoming, Laramie, USA. p. 97.

Kratz, M., Cullen, P., Kannenberg, F., Kassner, A., Fobker, M., Abuja, P.M., Assmann, G. \& Wahrburg, U., 2002. Effects of dietary fatty acids on the composition and oxidizability of low-density lipoprotein. Eur. J. Clin. Nutr. 56, 72-81.

Loor, J.J., Herbein, J.H. \& Polan, C.E., 2002. Trans18:1 and 18:2 isomers in blood plasma and milk fat of grazing cows fed a grain supplement containing solvent extracted or mechanically extracted soybean meal. J. Dairy. Sci. 85, 1197-1207.

Maddock, T.D., Bauer, M.L., Koch, K.B., Anderson, V.L., Maddock, R.J., Barcelo Coblijn, G., Murphy, E.J. \& Lardy, G.P., 2006. Effect of processing flax in beef feedlot diets on performance, carcass characteristics, and trained sensory panel ratings. J. Anim. Sci. 84, 1544-1551.

Marchello, J.A., Dryden, F.D., \& Hale, W.H., 1972. Bovine serum lipids. IV. The influence of added saturated and unsaturated fat to the ration. J. Anim. Sci. 35, 611-618. 
Moore, J.A., Swingle, R.S. \& Hale, W.H., 1968. Effects of whole cottonseed, cottonseed oil or animal fat on digestibility of wheat straw diets by steers. J. Anim. Sci. 63, 1267-1273.

Moore, J.H. \& Christie, W.W., 1984. Digestion, absorption and transport of fats in ruminant animals. In: Fats in Animal Nutrition, vol. 1. Ed. Wiscunian, J., Butterworths, London. pp. 123-149.

Moore, J.H., Noble, R.C. \& Steele, W., 1968. Factors affecting the polyunsaturated fatty acid content of the plasma lipids of sheep. Br. J. Nutr. 22, 681-688.

Muci, M.R., Cappello, A.R., Vonghia, G., Bellitti, E., Zezza, L. \& Gnoni, G.V., 1992a. Change in cholesterol levels and in lipid fatty acid composition in safflower oil fed lambs. Int. J. Vit. Nutr. Res. $62,330-333$.

Periago, J.L., Suarez, M.D. \& Pita, M.L., 1990. Effect of dietary olive oil, corn oil and medium chain triglycerides on the lipid composition of rat red blood cell membranes. J. Nutr. 120, 986-994.

Petit, H.V., 2002. Digestion, milk production, milk composition, and blood composition of dairy cows fed whole flaxseed. J. Dairy. Sci. 85, 1482-1490.

Ruckebusch, Y., Phaneuf, L.P. \& Dunlop, R.D., 1991. Physiology of Small and Large Animals. Decker, Hamilton, O.N., USA. pp. 233-253.

Rukkwamsuk, T., Geelen, M.J.H., Kruip, T.A.M. \& Wensing, T., 2000. Interrelation of fatty acid composition in adipose tissue, serum, and liver of dairy cows during the development of fatty liver postpartum. J. Dairy Sci. 83, 52-59.

SAS, 2004. Statistical Analysis Systems user's guide. SAS Institute Inc, Cary, N.C., USA.

Sato, H., 1974. Effects of dietary fat on lipid composition of serum and erythrocytes of the swine and in vitro incorporation of fatty acids into erythrocyte membranes. J. Nutr. Sci. Vit. 20, 451-469.

Sklan, D., Volcani, R. \& Budowski, P., 1972. Effects of diets low in fat or essential fatty acids on the fatty acid composition of blood lipids of calves. Br. J. Nutr. 27, 365-374.

Smith, J.E., 1987. Review: Erythrocyte membrane: structure, function, and pathophysiology. Vet. Path. 24, 471-476.

Van den Top, A.M., Wensing, Th. \& Beynen, A.C., 1995. Influence of replacement of dietary hay by an isoenergetic amount of a concentrate rich in medium chain triacylglycerols on fat metabolism in goats. J. Anim. Physiol. Anim. Nutr. 73, 104-112.

Van Soest, P.J., Robertson, J.B. \& Lewis, B.A., 1991. Methods for dietary fiber, neutral detergent fiber, and nonstarch polysaccharides in relation to animal nutrition. J. Dairy Sci. 74, 3583-3597.

Van Tol, A., Terpstra, A.H., Van den Bergh, P. \& Beynen, A.C., 1999. Dietary corn oil versus olive oil enhances HDL protein turnover and lowers HDL cholesterol levels in hamsters. Atherosclerosis 147, 87-94.

Vernon, R.G., 1975. Effect of dietary safflower oil upon lipogenesis in neonatal lamb. Lipids 10, 284-289.

Wardlaw, G.M., Snook, J.T., Lin, M.C., Puangco, M.A. \& Kwon, J.S., 1991. Serum lipid and apolipoprotein concentration in healthy men on diets enriched with canola oil or safflower oil. Am. J. Clin. Nutr. 54, 104-110.

Williams, C.M. \& Maunder, K., 1992. Effect of dietary fatty acid composition on inositol, choline and ethanolamine phospholipids of mammary tissue and erythrocytes in the rat. Br. J. Nutr. 68, 183-193.

Yeom, K.H., Schonewille, J.Th. \& Beynen, A.C., 2005. Fatty acid composition of plasma lipids and erythrocytes in adult goats in positive energy balance fed diets containing either olive or corn oil. Small Rumin. Res. 58, 25-32.

Yeom, K.H., Schonewille, J.Th., Everts, H., Zoet, J.M. \& Beynen, A.C., 2003. Impact of dietary soybean oil versus medium chain triglycerides on plasma fatty acids in goats. Small Rumin. Res. 48, 201-208.

Yeom, K.H., Van Trierum, G., Hovenier, R., Schellingerhout, A.B., Lee, K.W. \& Beynen, A.C., 2002. Fatty acid composition of adipose tissue in goat kids fed milk replacers with different contents of linolenic and linoleic acid. Small Rumin. Res. 43, 15-22. 